\title{
The Bus Decision: A Case Study Employing Capital Budgeting And Creative Thinking
}

Mark W. McCartney, Saginaw Valley State University, USA

Elizabeth M. Pierce, Saginaw Valley State University, USA

Wayne Mackie, Saginaw Valley State University, USA

\begin{abstract}
This paper presents a case whose setting is a regional university situated approximately twenty-five miles away from a community. The community is home to a significant number of the university's faculty, staff, and students. The university is asked to provide a commuter bus to transport people to and from the community. The university, in turn, approaches the community municipal bus service asking if it (the municipal bus service) could provide the requested route. The case incorporates cash flow management decision making including: (1) identifying necessary information for the analysis, (2) identifying appropriate analytical tools for the analysis, and (3) performing the analysis. This case is appropriate for first year graduate students, as well as upper level undergraduate business students. The case is designed to be taught in one class hour and is expected to require two hours of outside preparation by the students.
\end{abstract}

Keywords: Capital Budgeting; Net Present Value; Internal Rate Of Return; Decision Making

\section{INTRODUCTION AND LITERATURE}

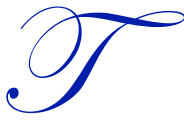

his paper presents a case involving the use of capital budgeting techniques on forecasted cash flows for a proposed municipal bus service route. Information in this case is based on an actual bus service. The setting is a regional university situated approximately twenty-five miles away from a community, with the community being the home of a significant number of the university's faculty, staff, and students. Some staff have requested a commuter bus to transport people to and from the community to the university. The university, in turn, approaches the community municipal bus service, asking if it would consider opening a dedicated bus line for faculty, staff, and students of the university, and what the fare charged the customers would be. The case puts students in the role of the bus service controller and her staff who prepare a cash flow analysis to decide what the estimated cost of the new line will be as well as what to charge users of the dedicated bus line, and involves identifying relevant costs and cash flows as well as the proper use of capital budgeting tools to analyze the cash flows. This case is based on an actual proposal and analysis for a regional university and community transit authority.

This case is unique in that the student works through the problem in three stages: (1) brainstorming to identify the many facets (customer demand for bus services, costs, other factors) which need to be considered in this decision; (2) identifying the appropriate analytical tools for this analysis (capital budgeting techniques), and; (3) using these capital budgeting analytical tools to arrive at an answer, the fare that should be charged users of this dedicated commuter bus line. It can be taught in one class session and is appropriate for upper division business students as well as for an introductory finance or accounting course at the graduate level.

An important aspect of this case involves brainstorming, which is linked to creative thinking. Employment of learning experiences in general business master's degree programs involving "thinking creatively" is advocated in AACSB accreditation standards (AACSB, 2013, p. 32). In analyzing this case, students are first asked to brainstorm to identify information needed to thoroughly analyze the problem. Brainstorming is defined as "The action or process of making a concerted attempt to solve a problem, usually by a group discussion of spontaneously arising ideas (Brainstorming, n.d.). In developing creative thinking skills, brainstorming is described by Trumfio as an activity whose goal "is to have people plunge deep inside themselves, yank out those creative thoughts, and put 
them into action" (Trumfio, 1995, p. 147). Brainstorming is considered to be a cognitive process which plays a major role in creativity (Bonnardel \& Didier, 2016, p. 98) and is described as perhaps "the most well-known creativity technique" (Green, 2007, p. 89). In an experiment, Bonnardel \& Diddier (2016) supported the hypothesis that short training sessions involving brainstorming can influence creative processes. Pun (2014) employed a pedagogical model designed to enhance creative thinking, with a focus of the model on group brainstorming, and found that the model used was well suited to nurture creative thinking.

Another important aspect of the case is the employment of capital budgeting tools to analyze the feasibility of implementing the bus route. Capital budgeting tools have long been used by organizations to assist in making informed decisions about capital expenditures. Ryan \& Ryan (2002), in a survey of Fortune 1000 businesses, reported that, historically, managers have seemed to prefer IRR (internal rate of return) over NPV (net present value analysis), with the consensus being that IRR is easier to understand cognitively. However, they further reported that there are indications that NPV is becoming more popular based on the detail provided by the analysis. They found that $99.5 \%$, use capital budgeting analyses, however, the minimum level of expenditure triggering these analyses varied greatly (Ryan \& Ryan, 2002). When surveyed about methods used, NPV was used by $49.8 \%$ of organizations and IRR by $44.6 \%$ (Ryan \& Ryan, 2002). This contrasts with $29 \%$ of companies using NPV in a survey of the Fortune 500 companies by Burns \& Walker (1997). They also reported that the companies indicated an increased use of NPV over the prior 5-10 years (Burns \& Walker, 1997).

Following are a few case studies on capital budgeting. Boudreaux \& Rao (2010) presented a case study in which a business used capital budgeting techniques (NPV, IRR, profitability index, payback) to assist in deciding how best to increase production capacity for a sugar cane refinery. Meric et al. (2010) described a case using capital budgeting tools to assist in purchase decisions for new processing systems. A case using capital budgeting in realestate development decisions is presented by Murtagh (2010), and Sylvester (2012) presents a situation in which students gather information about pre-and after-tax cash flows to prepare analysis of an unstructured capital budgeting business decision. The next section of this paper (The Case) presents the case, followed by Results, showing the case solution.

\section{THE CASE}

Anita Night, a librarian at Valley University, lives in the community of Midtown, a community of approximately 45,000 residents; twenty-five miles from school. She had been thinking about her commute to work for some time now; gas was over $\$ 4$ a gallon and her car was approaching the 100,000 mile mark. After discussions with several friends who make the same commute, she and her friends were wondering if a commuter bus would be an option that might benefit both the people who make the drive and simultaneously be profitable to the university.

Anita met with Geoff Newman, Vice President of Business Affairs, to see if Valley University would consider purchasing a bus for this purpose. She opined there were quite a few people who live in Midtown who drive to the university and that they would gladly pay a fare to cover the bus costs. Benefits would include a reduced "carbon footprint" and significantly fewer miles being driven on the cars used by these people.

Geoff met with his staff and the president of the university to consider this service. After the meeting he met with Anita to explain the university's position. While everyone liked the thought of providing the bus service, he explained, the university just isn't in the business of providing transportation to its employees. Valley University doesn't have the facilities or staff to maintain the equipment and there is risk that this would lose money and cost the university financially. He said, "Try explaining to the students why their tuition is going toward a commuter bus to Midtown!"

Geoff then offered an alternative; that university officials would meet with MARTS, Midtown Authority Regional Transit Services. Perhaps they would add a dedicated bus line to Valley University. MARTS is a public transportation system for the urbanized Midtown Area, which travels about 1.5 million miles per year. Over 2,700 people ride MARTS buses each day to work, doctor visits, shopping or school. People pay a minimal fare ( $\$ 1.25$ per fixed route), with MARTS being subsidized through a combination of tax dollars and other public funds. 
A week later Geoff met with Penny Kekel; controller for MARTS. Penny explained that such a service would be out of MARTS regional jurisdiction, and as such it cannot be subsidized through any public funding. In effect, the service would have to be paid for entirely by user fares, and would be operated on a "for profit" basis. Geoff said the university would still be interested, and asked Penny if a proposal could be put together, culminating in the fare that would be charged commuter bus users. Penny agreed and added that because this would be a separate service operated for a profit, they would purchase a bus (or busses) for this service rather than use busses from the existing fleet.

\section{Discussion Questions:}

Assume you are Penny Kekel.

1. What are questions which need to be answered to arrive at a minimum fare to charge customers for MARTS to open this commuter bus service?

2. What analytical techniques should be employed to analyze the data in \#1? Give a brief description of each of these techniques.

3. Perform the analyses. What should MARTS minimum fare be?

\section{TEACHER'S NOTES}

\section{Questions for Analysis:}

1. How many people will use the commuter bus service?

2. What times during the day will the service make the commute? How many miles will be driven each day?

3. What will be anticipated daily demand for each of bus trip during the day?

4. What types of busses are available? What is the cost of theses busses? What is the life of these busses?

5. Given the scheduled demand in \#3 and the type of bus selected, how many busses are needed?

6. What is maintenance cost expected to be?

7. What is fuel cost expected to be?

8. What happens if the bus breaks down, what will be used as backup and what will this cost?

9. What will be done if more people want to ride than the bus can handle? What will the cost be?

10. How will the bus be staffed? What will be employee cost?

11. What will the route be?

12. How many days a week will the service be in operation?

13. How many weeks will the bus service be in operation?

14. What should the profit/return be for MARTS?

15. For what period of time should the analyses be performed?

\section{Answers to Questions for Analysis:}

1. Valley University's department of institutional research revealed that 116 faculty and staff as well as 464 students lived in Midtown. These people were surveyed and an analysis of the results lead to a projection that approximately 200 would use the commuter service.

2. The bus schedule for Monday - Thursday will be: 7:20am - Midtown to Valley University then back to Midtown; 12:00pm - Midtown to Valley University then back to Midtown; 4:45pm, Midtown to Valley University then back to Midtown; 9:30pm - Midtown to Valley University then back to Midtown. The 9:30pm service exists due to the large number of students and faculty who take and teach night classes at Valley University. The Friday bus schedule will be limited: 7:20am - Midtown to Valley University then back to Midtown; $12: 00 \mathrm{pm}$ - Midtown to Valley University then back to Midtown; 4:45pm, Midtown to Valley University then back to Midtown; no 9:30 service. Each twoway commute will total 50 miles. 
3. Best estimate for daily demand is as follows, and also shown in Table 1.

a. Monday - Thursday

i. 7:20am: 125 passengers will depart Midtown for Valley U, 30 will return to Midtown at noon, 85 will return to Midtown at $4: 45 \mathrm{pm}, 10$ will return to Midtown at 9:30pm.

ii. Noon: 50 passengers will depart Midtown for Valley U, 30 will return to Midtown at 4:45pm, 20 will return to Midtown at 9:30pm.

iii. 4:45pm: 25 passengers will depart Midtown for Valley U, and all 25 will return to Midtown at 9:30pm.

b. Friday

i. 7:20am: 50 passengers will depart Midtown for Valley U, 10 will return to Midtown at noon, 40 will return to Midtown at $4: 45 \mathrm{pm}$.

ii. Noon: 15 passengers will depart Midtown for Valley U, all 15 will return to Midtown at $4: 45 \mathrm{pm}$.

4. A $35^{\prime}, 32$ passenger vehicle can be acquired for $\$ 335,000$. These vehicles have an estimated life of 12-years or 500,000 miles. These are diesel engine vehicles. A 22', 8-11 passenger lift bus can be acquired for $\$ 55,000$, which has a 7-year, 200,000 mile life.

5. Peak demand will be Monday through Thursday at 7:20am (125 passengers) and 4:45pm (115 passengers). As such, four, 32 passenger busses will be needed to accommodate those two peak times, as shown in Table 2.

6. Utilizing budget numbers from previous years, the average maintenance cost per vehicle is approximately $\$ 5,800$ per year. This is projected to grow at $5 \%$ per year.

7. The bus authority is given various cost abatements with regard to fuel, and after abatements the average fuel cost for this year is expected to be $\$ 2.18$ per gallon. The 32 passenger bus averages 3.80 miles per gallon. This fuel cost is projected to increase at an average of $6 \%$ per year.

8. If a bus breaks down, MARTS will immediately dispatch a backup bus to the scene. The cost of dispatching this bus will be $\$ 500$, and includes mileage, driver salary, etc. Busses are well maintained, and this is expected to seldom happen, perhaps four times per year. This cost is expected to increase approximately $5 \%$ per year.

Table 1. Projected Bus Schedule and Passengers

\begin{tabular}{|c|c|c|}
\hline Passengers: Monday - Th & & \\
\hline Departure & Midtown $\rightarrow$ Valley University & Valley University $-\rightarrow$ Midtown \\
\hline 7:20am & 125 & 0 \\
\hline Noon & 50 & 30 \\
\hline $4: 45 \mathrm{pm}$ & 25 & 115 \\
\hline $9: 30 \mathrm{pm}$ & 0 & 55 \\
\hline
\end{tabular}

Passengers: Friday

\begin{tabular}{|c|c|c|}
\hline Departure & Midtown $\rightarrow$ Valley University & Valley University $-\rightarrow$ Midtown \\
\hline 7:20am & 50 & 0 \\
\hline Noon & 15 & 10 \\
\hline $4: 45 \mathrm{pm}$ & 0 & 55 \\
\hline $9: 30 \mathrm{pm}$ & No service & No service \\
\hline
\end{tabular}

Table 2. Busses Needed (32 passenger)

\begin{tabular}{|c|c|c|}
\hline Departure & $\begin{array}{l}\text { Peak Demand } \\
\text { (one way) }\end{array}$ & $\begin{array}{c}\text { Buses } \\
\text { Needed }\end{array}$ \\
\hline 7:20am & 125 & 4 \\
\hline Noon & 50 & 2 \\
\hline $4: 45 \mathrm{pm}$ & 115 & 4 \\
\hline $9: 30 \mathrm{pm}$ & 55 & 2 \\
\hline
\end{tabular}

9. If a bus is full with more people wanting to ride, an additional bus will be immediately dispatched. The cost will be $\$ 350$ for a $22^{\prime}, 8-11$ passenger lift bus or $\$ 500$ for the $35^{\prime}, 32$ passenger vehicle. The 
authority decided to project this would happen ten times throughout a year, and that the $8-11$ passenger bus would be dispatched. This cost per bus is projected to increase $5 \%$ per year.

10. The salary for a bus driver is $\$ 36,500$ per year, including overtime, shift premiums, and other costs. Fringe benefits total $\$ 21,550$. It is estimated that this route will use the services of one and one half (1 $1 / 2$ ) drivers throughout the year, put another way, one driver full time and second driver half time. This is expected to increase approximately $3 \%$ per year.

11. A daily bus route will be directly from Midtown to Valley University and back to Midtown, a drive of fifty miles, round trip.

12. The commuter service will operate 5 days per week, with limited service on Friday.

13. The bus service will be in operation when school is open. This would be fifteen weeks for each of the three semesters; fall, winter, and spring/summer, total of 45 weeks.

14. Given the riskiness and uncertainty involved in this service, MARTS would like to use a $25 \%$ return per year as its hurdle rate.

15. MARTS decided to use the bus life as the time frame for this analysis, 500,000 miles or 12 years.

\section{Analytical Techniques:}

Capital budgeting techniques would be most appropriate for evaluating this decision. Three commonly used capital budgeting techniques are cash payback, net present value, and internal rate of return.

- Cash payback - the expected period of time between the date of an investment and the recovery in cash of the amount invested (Warren, 2015, p. 622).

- Net present value - compares the amount to be invested with the present value of the net cash inflows (Warren, 2015, p. 626). An interest rate is needed to determine the present value of future cash flows. Factors used in determining this rate include the risk of the investment, cost of obtaining funds, etc. A positive net present value indicates that the present value of the cash inflows exceeds the amount to be invested, making the investment a desirable investment.

- Internal rate of return - uses present value concepts to compute the rate of return from a capital investment proposal (Warren, 2015, p. 628).

\section{Analyses to Determine Minimum Fare:}

There are many assumptions that can be made in arriving at a minimum fare. The solution shown here assumes the busses are stationed at Midtown, then dispatched from Midtown to Valley University, then back to Midtown at 7:20am, noon, $4: 45 \mathrm{pm}$, and 9:30pm, totaling four round trips Monday through Thursday, and three round trips ( $7: 20 \mathrm{am}$, noon, $4: 45 \mathrm{pm})$ on Friday. The average one-way fare to charge to earn a $25 \%$ rate of return is $\$ 7.43$. The solution uses Microsoft excel, with columns for the costs and revenue. The solution is shown in Table 3. 
Table 3. Capital Budgeting Analysis

\begin{tabular}{|c|c|c|c|c|c|c|c|c|}
\hline & $\begin{array}{c}\text { Cost of } 4,32 \\
\text { seat busses } \\
\text { (1) }\end{array}$ & $\begin{array}{c}\text { Price of one } \\
\text { way fare }\end{array}$ & $\begin{array}{c}\text { Total fare } \\
\text { revenue } \\
(2) \\
\end{array}$ & $\begin{array}{c}\text { Fuel cost } \\
\text { (3) }\end{array}$ & $\begin{array}{c}\text { Maintenance } \\
\text { Cost } \\
(4) \\
\end{array}$ & $\begin{array}{c}\text { Dispatch } \\
\text { emergency bus } \\
\text { (5) }\end{array}$ & $\begin{array}{c}\text { Driver salary } \\
(6)\end{array}$ & $\begin{array}{c}\text { Net cash } \\
\text { inflow / } \\
\text { (outflow) }\end{array}$ \\
\hline Day 1 & $\$ 1,340,000$ & & & & & & & $(\$ 1,340,000)$ \\
\hline \multicolumn{9}{|l|}{ Year } \\
\hline 1 & & $\$ 7.43$ & $\$ 572,976$ & $\$ 68,412$ & $\$ 23,200$ & $\$ 5,500$ & $\$ 87,075$ & $\$ 394,239$ \\
\hline 2 & & 7.43 & 572,976 & 72,517 & 24,360 & 5,775 & 89,687 & 386,087 \\
\hline 3 & & 7.43 & 572,976 & 76,868 & 25,578 & 6,064 & 92,378 & 377,538 \\
\hline 4 & & 7.43 & 572,976 & 81,480 & 26,857 & 6,367 & 95,149 & 368,573 \\
\hline 5 & & 7.43 & 572,976 & 86,368 & 28,200 & 6,685 & 98,004 & 359,168 \\
\hline 6 & & 7.43 & 572,976 & 91,550 & 29,610 & 7,020 & 100,944 & 349,302 \\
\hline 7 & & 7.43 & 572,976 & 97,044 & 31,090 & 7,371 & 103,972 & 338,949 \\
\hline 8 & & 7.43 & 572,976 & 102,866 & 32,645 & 7,739 & 107,091 & 328,084 \\
\hline 9 & & 7.43 & 572,976 & 109,038 & 34,277 & 8,126 & 110,304 & 316,680 \\
\hline 10 & & 7.43 & 572,976 & 115,580 & 35,991 & 8,532 & 113,613 & 304,709 \\
\hline 11 & & 7.43 & 572,976 & 122,515 & 37,790 & 8,959 & 117,022 & 292,140 \\
\hline
\end{tabular}

Internal rate of return: $25 \%$

Net present value: $\$ 2,456$

Payback: $\quad 4^{\text {th }}$ year

(1) $\$ 335,000 \times 4$ buses $=\$ 1,340,000$.

(2) 1,730 fares per week $x 45$ weeks $x \$ 7.36=\$ 572,976$. Fares per week, see Table 4 .

(3) 119,250 miles $/ 3.8 \mathrm{mpg}=31,382$ gallons; 31,382 gallons $\mathrm{x} \$ 2.18=\$ 68,412$, then $6 \%$ per year increase. Miles driven per year, see Table 5 .

(4) $\$ 5,800$ per bus $x 4$ buses $=\$ 23,200$, then $5 \%$ per year increase.

(5) Breakdowns $\$ 500$ per dispatch $\times 4$ dispatches $=\$ 2,000$; over capacity $\$ 350$ per dispatch $\times 10$ dispatches $=\$ 3,500$; total $\$ 2,000+\$ 3,500=\$ 5,500$, then $5 \%$ per year increase.

(6) $\$ 36,500$ salary $+\$ 21,550$ benefits x $1 \frac{1}{2}$ drivers, then $3 \%$ per year increase.

Note: to perform this analysis in excel, the net present value and internal rate of return functions are performed on the Net cash inflow/(outflow) column. Total fare revenue is the amount entered into the "Price of one-way fare" column x 1,730 fares x 45 weeks. Enter dollar amounts into the "Price of one-way fare" column until IRR is $25 \%$ and NPV is just above zero.

Table 4. Bus Fares per Week

\begin{tabular}{|c|c|c|c|c|}
\hline & Fares daily & Days & Total & \\
\hline \multicolumn{5}{|l|}{ Monday - Thursday } \\
\hline $7: 20 \mathrm{am}$ & 125 & 4 & 500 & \\
\hline Noon & 80 & 4 & 320 & \\
\hline $4: 45 \mathrm{pm}$ & 140 & 4 & 560 & \\
\hline \multirow{2}{*}{$9: 30 \mathrm{pm}$} & 55 & 4 & 400 & \\
\hline & & & & 1,600 \\
\hline \multicolumn{5}{|l|}{ Friday } \\
\hline 7:20am & 50 & 1 & 50 & \\
\hline Noon & 25 & 1 & 25 & \\
\hline \multirow[t]{2}{*}{$4: 45 \mathrm{pm}$} & 55 & 1 & 55 & \\
\hline & & & & 130 \\
\hline Estimated fares per week & & & & 1,730 \\
\hline
\end{tabular}


Table 5. Bus Miles Driven per Year

\begin{tabular}{|c|c|c|c|c|c|}
\hline & Buses needed & Miles (round trip) & Days & Miles per trip & \\
\hline \multicolumn{6}{|l|}{ Monday - Thursday } \\
\hline $7: 20 \mathrm{am}$ & 4 & 50 & 4 & 800 & \\
\hline Noon & 2 & 50 & 4 & 400 & \\
\hline $4: 45 \mathrm{pm}$ & 4 & 50 & 4 & 800 & \\
\hline $9: 30 \mathrm{pm}$ & 2 & 50 & 4 & 400 & \\
\hline Total Monday - Thursday & & & & & 2,400 \\
\hline \multicolumn{6}{|l|}{ Friday } \\
\hline $7: 20 \mathrm{am}$ & 2 & 50 & 1 & 100 & \\
\hline Noon & 1 & 50 & 1 & 50 & \\
\hline \multirow[t]{2}{*}{$4: 45 \mathrm{pm}$} & 2 & 50 & 1 & 100 & \\
\hline & & & & & 250 \\
\hline Total Friday & & & & & 2,650 \\
\hline Weeks & & & & & 45 \\
\hline Total miles per year & & & & & 119,250 \\
\hline
\end{tabular}

\section{AUTHOR BIOGRAPHIES}

Mark McCartney, CPA, PhD, is a Professor of Accounting and Chair of the Department of Accounting, Law, and Finance at Saginaw Valley State University in University Center, MI. He teaches intermediate accounting, fund accounting, accounting courses at the MBA level, and occasionally an introductory accounting course.

Elizabeth Pierce, CPA, PhD, is an Assistant Professor of Accounting at Saginaw Valley State University. She earned her CPA and was practicing in the accounting field, then returned to academe and graduated with a PhD in Immunology from The University of Michigan. She researched in the Immunology field, then returned to accounting academe after successfully completing the AACSB Bridge to Business Program. She teaches accounting information systems, cost, managerial, and financial accounting.

Wayne Mackie, $\mathrm{PhD}$, is a Professor of Finance at Saginaw Valley State University. Wayne's passion is investments and personal financial planning. He teaches corporate, real estate, insurance, and investment finance courses.

\section{REFERENCES}

AACSB International - The Association to Advance Collegiate Schools of Business. (2013) (2016 update). Eligibility Procedures and Accreditation Standards for Business Accreditation. Retrieved from: http://www.aacsb.edu/accreditation/standards/2013-business.

Bonnardel, N., \& Didier, J. (2016). Enhancing creativity in the educational design context: An exploration of the effects of design project-oriented methods on students' evocation processes and creative output. Journal of Cognitive Education and Psychology, 15(1), 80-101.

Boudreaux, D. O., \& Rao, S.P. (2010). Sugar Cane Refining and Processing Company: A comprehensive case in capital budgeting. Journal of Business Case Studies, 6(6), 111-116.

Brainstorming (n.d.). In Oxford English Dictionary Online. Retrieved from http://0www.oed.com.library.svsu.edu/view/Entry/304170?redirectedFrom=brainstorming\#eid.

Burns, R. M., \& Walker, J. (1997). Capital budgeting techniques among the Fortune 500: A rationale approach. Managerial Finance, 23(9), 3-15.

Green, A. (2007). Creativity in Public Relations, ( $3^{\text {rd }}$ ed.). London, UK: Kogan Page Ltd., (Chapter 6).

Meric, I., Dunne, K., Li, S. F., \& Gulser, M. (2010). Variety Enterprises Corporation: Capital budgeting decision. Review of Business \& Finance Case Studies, 1(1), 15-20.

Murtagh, J. P. (2010). The Water's Edge Apartments: Capital budgeting in real estate development. Journal of Business Case Studies, 6(6), 1-6.

Pun, S. K. (2014). Pedagogy for creative collaboration. Business Education \& Accreditation (6)2, 89-98.

Ryan, P. A., \& Ryan, G. P. (2002). Capital budgeting practices of the Fortune 1000: How have things changed? Journal of Business and Management, 8(4), 355-364. 
Silvester, K. J. (2012). Coffee anyone? An unconstructed capital budgeting project to encourage critical thinking skills in accounting students. Journal of Business Case Studies, 8(2), 223-236.

Trumfio, G. (1995). Brainstorming for fun and profit. Sales and Marketing Management (147)1, 30.

Warren, C. S. (2015). Survey of Accounting. ( $7^{\text {th }}$ ed.). Mason, OH: South-Western/Cengage Learning, (Chapter 15). 